\section{Message from President}

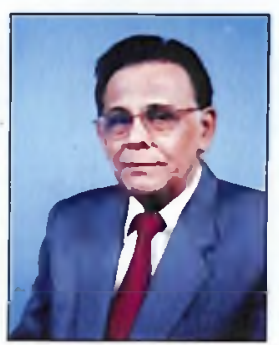

Dear friends,

I am just back after successful completion of a memorable event during my tenure as President of the institute The International Welding Congress IIW-IC-2008, an event of the International Institute of Welding held during 8-10th January 2008 at the Chennai Trade Centre, Nandambakkam, Chennai on the theme "Technological and Material challenges in Welding, Fabrication and Inspection". This is the 2nd time when our Institute organized such a mega event. During the Congress, the 60th Anniversary of International Institute of Welding was also celebrated. Further, an Exhibition "Weld India 2008" and a Technology Innovation Workshop which was felicitated by Mr. Chris Smallbone, President, International Institute of Welding was also arranged.

On the whole, the Congress was an all out success and this has helped us to be awarded with the responsibility to organize the Annual Assembly, the greatest event of the International Institute of Welding to be held for the first time in India on 2011. I seek the wholehearted support and co-operation in advance from all of you for efficiently organizing this mega event.

The 13th ESSEN Welding \& Cutting Fair 2008 is going to be held during 14-17th May 2008 at Beijing, China. To share knowledge on Welding \& Cutting Technology, do not miss the opportunity of visiting this Fair. Also the 61 st Annual Assembly and International Conference of the International Institute of Welding is being held from 6th July, 2008 at Graz, Austria. If you are interested to participate, please contact IIW-HO for details.

Hope, you have received the last quarterly issue, i.e. October ' 07 issue of IWJ in which you may have noticed that Technical content and quality of the journal has substantially improved. To make further development, we need more advertisement support from you

I am also happy to note that ANB-India, a division of your Institute has already organized 2-Refresher Courses at Kolkata and Mumbai for awarding diplomas through Transition Arrangement approved by IAB and subsequently 23 candidates received international level diploma certificates during the inaugural ceremony of IIWIC-2008 from the President of the International Institute of Welding. I congratulate the successful awardees and call upon al! eligible members and your friends to avail the opportunity of attaining international level qualifications in Welding from ANB-India.

With all my best wishes.

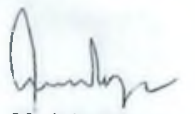

A. K! Mukherjee

President

The Indian Institute of Welding
Message from Hony. Secretary General's Desk

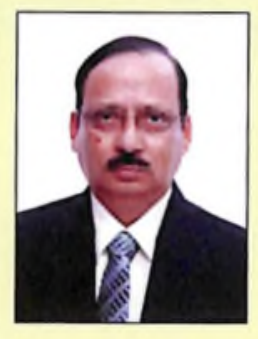

DearMembers,

At the outset let me congratulate, on behalf of the Central Council, the Organizing Committee ICIIW-2008 and in particular the Managing Committee of Chennai Branch for holding a very successful event - International Welding Congress -2008 at Chennai Trade Centre, Chennai. During the Congress we concurrently celebrated the 60th anniversary of International

Institute of Welding . The commemorative monograph on "Welding Science and Technology Competence" and postage stamp were published at the inaugural function and the President of the International Institute of Welding Mr Chris Smallbone and other dignitaries appreciated very much and we also received a letter from Mr. Chris Smallbone in this regard.

We need to give more thrust for enrolment of new members. I urge upon all Branch Managing Committees to put their effort for revival of defaulting members as well as enrolling new membership. During the Congress, many delegates who are not presently members of the Institute had shown keen interest to become members of our institute and some of the delegates even submitted applications on the spot. We are trying to forward the list of all the delegates who participated in the congress to your branch as soon as we receive the same from our Chennai Branch and I would request you to contact the persons who belong to your workplace and enrol them as a members of the Institute.

During the last 260th Council Meeting at Chennai, National Welding Meet 2008 (NWM-2008) was awarded to Visakhapatanam Branch scheduled to be held in August '08 and National Welding Seminar 2008 (NWS-2008) was awarded to Mumbai Branch scheduled to be held in December 2008. I would request all the members of the Institute to extend their fullest co-operation to both the branches.

During the Congress, on 9 th January ' 08 , the fourth Annual Members Assembly was held. A large number of members attended this Assembly and participated in the discussion and expressed their valued opinion and suggestion for the growth of the Institute.

You are aware that IIW is always making efforts to establish cooperation between manufactures and users. As a part of this programme for the last four years we are organizing visits for participation at different welding fairs in the world for our Members. The 13th Beijing Essen Welding \& Cutting Fair scheduled to be held from 14-17 May, 2008 at China International Exhibition Centre, Beijing We have made tie-up with Orbitz Corporate \& Leisure Travels (l) Pvt. Ltd. 220/1, A.J.C. Bose Road, Kolkata-17, Tel: $+913322896151-4$, for this purpose. Members interested may please contact them or us for the visit to the Fair.

We are now in the map of the International Institute of Welding. We will be hosting the IIW Annual Assembly in India in 2011 After very successful conduction of International Congress 2005 \& 2008 we are confident that we will be able to conduct the Assembly also very successfully and it will be only possible if all of us put all out efforts collectively.

Let us work together to take this Institute to a greater height. With warm regards.

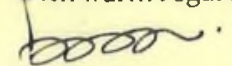

Parimal Biswas

Email : iiw.secgen_parimal@yahoo.co.in 